\title{
A case report of pulmonary Botrytis sp. infection in an apparently healthy individual
}

\author{
Seishu Hashimoto 1*, Eisaku Tanaka', Masakuni Ueyama', Satoru Terada', Takashi Inao', Yusuke Kaji',

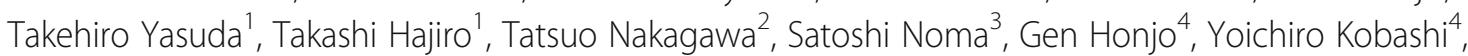 \\ Noriyuki Abe ${ }^{5}$, Katsuhiko Kamei ${ }^{6}$ and Yoshio Taguchi ${ }^{1}$
}

\begin{abstract}
Background: Botrytis species are well known fungal pathogens of various plants but have not been reported as human pathogens, except as allergenic precipitants of asthma and hypersensitivity pneumonitis.

Case presentation: The asymptomatic patient was referred because of a nodule revealed by chest X-ray. Computed tomography (CT) showed a cavitary nodule in the right upper lobe of the lung. He underwent wedge resection of the nodule, which revealed necrotizing granulomas and a fungus ball containing Y-shaped filamentous fungi, which was confirmed histopathologically. Culture of the specimen yielded white to grayish cotton-like colonies with black sclerotia. We performed multilocus gene sequence analyses including three single-copy nuclear DNA genes encoding glyceraldehyde-3-phosphate dehydrogenase, heat-shock protein 60, and DNA-dependent RNA polymerase subunit II. The analyses revealed that the isolate was most similar to Botrytis elliptica. To date, the pulmonary Botrytis sp. infection has not recurred after lung resection and the patient did not require any additional medication.

Conclusions: We report the first case of an immunocompetent patient with pulmonary Botrytis sp. infection, which has not recurred after lung resection without any additional medication. Precise evaluation is necessary for the diagnosis of pulmonary Botrytis infection because it is indistinguishable from other filamentous fungi both radiologically and by histopathology. The etiology and pathophysiology of pulmonary Botrytis infection remains unclear. Further accumulation and analysis of Botrytis cases is warranted.
\end{abstract}

Keywords: Botrytis sp., Pulmonary infection, Immunocompetent host, DNA sequence analysis

\section{Background}

Botrytis species are important pathogens of nursery plants, vegetables, orchard crops, and can colonize stored and transported agricultural products [1]. In particular, Botrytis cinerea is responsible for gray mold disease on more than 200 host plants [2] and has been isolated from numerous places around the world, especially humid, temperate and subtropical regions [1-3]. In contrast, winegrowers and viniculturists sometimes welcome $B$. cinerea, which facilitates a concentrated

\footnotetext{
* Correspondence: hassy@tenriyorozu.jp

${ }^{1}$ Department of Respiratory Medicine, Tenri Hospital, 200 Mishima-cho, Tenri, Nara 632-8552, Japan

Full list of author information is available at the end of the article
}

sweet wine in the right conditions. With regard to other Botrytis species, B. squamosa, $B$. allii, and B. aclada attack bulbs of onion, garlic and leek, while B. tulipae and B. elliptica attack flower bulbs such as tulip and lily.

Airborne exposure to Botrytis sp. has been reported globally but the prevalence of Botrytis is different by regions and seasons. Botrytis exposure is especially significant in occupational setting such as greenhouses and grain mills. Although many people may inhale spores of Botrytis species, it is of interest that Botrytis species have not been reported as human pathogens, except as allergenic precipitants of asthma and hypersensitivity pneumonitis [3].

(c) The Author(s). 2019 Open Access This article is distributed under the terms of the Creative Commons Attribution 4.0 International License (http://creativecommons.org/licenses/by/4.0/), which permits unrestricted use, distribution, and reproduction in any medium, provided you give appropriate credit to the original author(s) and the source, provide a link to the Creative Commons license, and indicate if changes were made. The Creative Commons Public Domain Dedication waiver (http://creativecommons.org/publicdomain/zero/1.0/) applies to the data made available in this article, unless otherwise stated. 
We report an apparently immunocompetent Japanese man with pulmonary Botrytis sp. infection, which to date has not recurred after lung resection.

Preliminary results of this case report have been presented in a poster discussion at the annual meeting of the American Thoracic Society [4].

\section{Case presentation}

A 62-year-old Japanese man from Tenri City in Nara prefecture was referred to our hospital because of a nodular shadow on chest X-ray taken at a regular health checkup. He did not have cough, sputum, hemoptysis, fever, night sweats, chest pain and weight loss. He had smoked two packs of cigarettes per day for 30 years until 12 years previously and occasionally consumed alcohol. $\mathrm{He}$ was an office worker and had been to China and Taiwan on business for several days approximately 30 years previously. He had no known occupational or inhalational exposures. He had never grown any plants, fruits, or vegetables. He had diabetes mellitus, hyperlipidemia and gout and had been treated with a combination of mitiglinide and voglibose, vildagliptin, rosuvastatin, and allopurinol. He had no known tuberculosis, bronchiectasis, or allergies. Family history was unremarkable and there was no family history of fungal disease. On examination, his temperature was $36.4^{\circ} \mathrm{C}$, blood pressure $144 / 88 \mathrm{mmHg}$, and resting pulse was 85 beats per minute, with 12 breaths per minute. The oxygen saturation was $98 \%$ while breathing ambient air. $\mathrm{He}$ had normal vesicular sounds on auscultation. The remainder of the examination was normal.

A chest X-radiograph showed a cavitary nodule in the right upper lung field (Fig. 1b), which was not seen on X-ray film taken 18 months previously (Fig. 1a). Computed tomography (CT) revealed a nodule with cavitary lesion, measuring $25 \mathrm{~mm}$ in diameter, in the right upper lobe (Fig. 2a). ${ }^{18} \mathrm{~F}$-fluorodeoxy-glucose positron emission tomography revealed mild accumulation in the nodule
( maximum standardized uptake value $=2.2$ ). Laboratory tests (Table 1) showed that serum creatinine was elevated at $1.2 \mathrm{mg} / \mathrm{dL}$. The hemoglobin level, white cell and platelet counts, and results of coagulation and liver function were normal. C-reactive protein was below $0.2 \mathrm{mg} /$ $\mathrm{dL}$. The erythrocyte sedimentation rate was slightly elevated at $12 \mathrm{~mm} / \mathrm{h}$. Serum tests for 1, 3- $\beta$-D-glucan, Aspergillus antigen, anti-Aspergillus antibody, and Cryptococcus antigen were all negative. Hemoglobin A1c was normal at 5.6\%. Both anti-human immunodeficiency virus antibody and anti-human T-cell leukemia virus type 1 antibody were negative. Bronchoscopic examination was performed, and bronchial brush specimens and bronchial washing fluids were obtained under fluoroscopy. However, the examination revealed no remarkable malignant cells or microorganisms including fungi and mycobacteria. Wedge resection of the cavitary nodule in the right upper lobe using video-assisted thoracoscopy was undergone to diagnose the nodule and exclude malignancy.

Histopathological examination of the resected specimen showed necrotizing granulomas and a fungus ball containing Y-shaped filamentous fungi (Fig. 2b-f). Grocott's methenamine silver stain revealed that the septated hyphae branched dichotomously (Fig. 2g). Vascular invasion was not seen in the tissue. The histopathological features resembled those of chronic cavitary pulmonary aspergillosis.

The lung biopsy material was cultured for fungi, mycobacteria and other bacteria. Because molds were observed in the intraoperative frozen section, culture for fungi was incubated at $25^{\circ} \mathrm{C}$ on potato dextrose agar (PDA) for 7 days. The culture yielded white to grayish cotton-like colonies with black sclerotia around the colonies (Fig. 3a). No other microorganisms were isolated. The multilocus gene sequence analyses identified the fungus as Botrytis sp. as shown in Tables 2, 3, 4 and Additional file 1: Figures S1-S5. He was diagnosed with

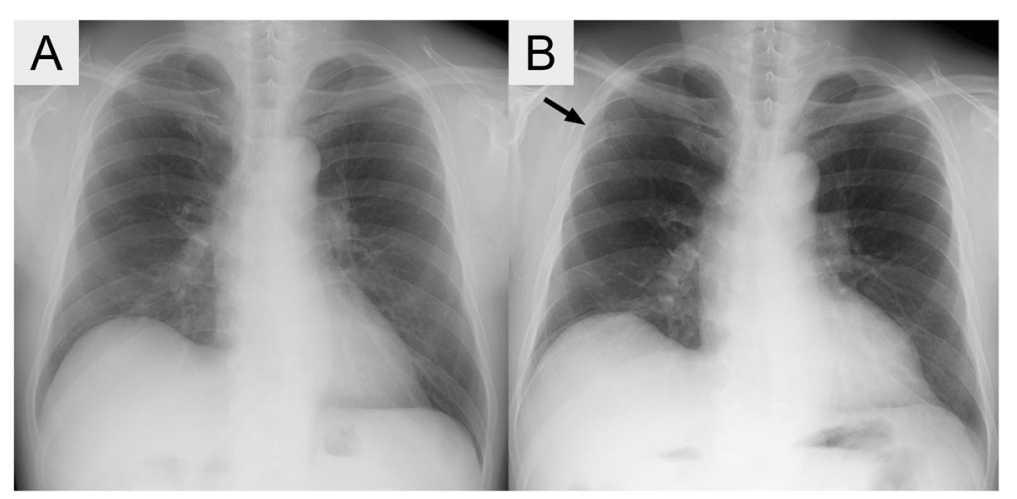

Fig. 1 Imaging studies of the chest. a A chest X-radiograph obtained 18 months earlier reveals no abnormal findings. $\mathbf{b}$ A chest X-radiograph on admission shows a cavitary nodule (arrow) in the right upper lung field. 


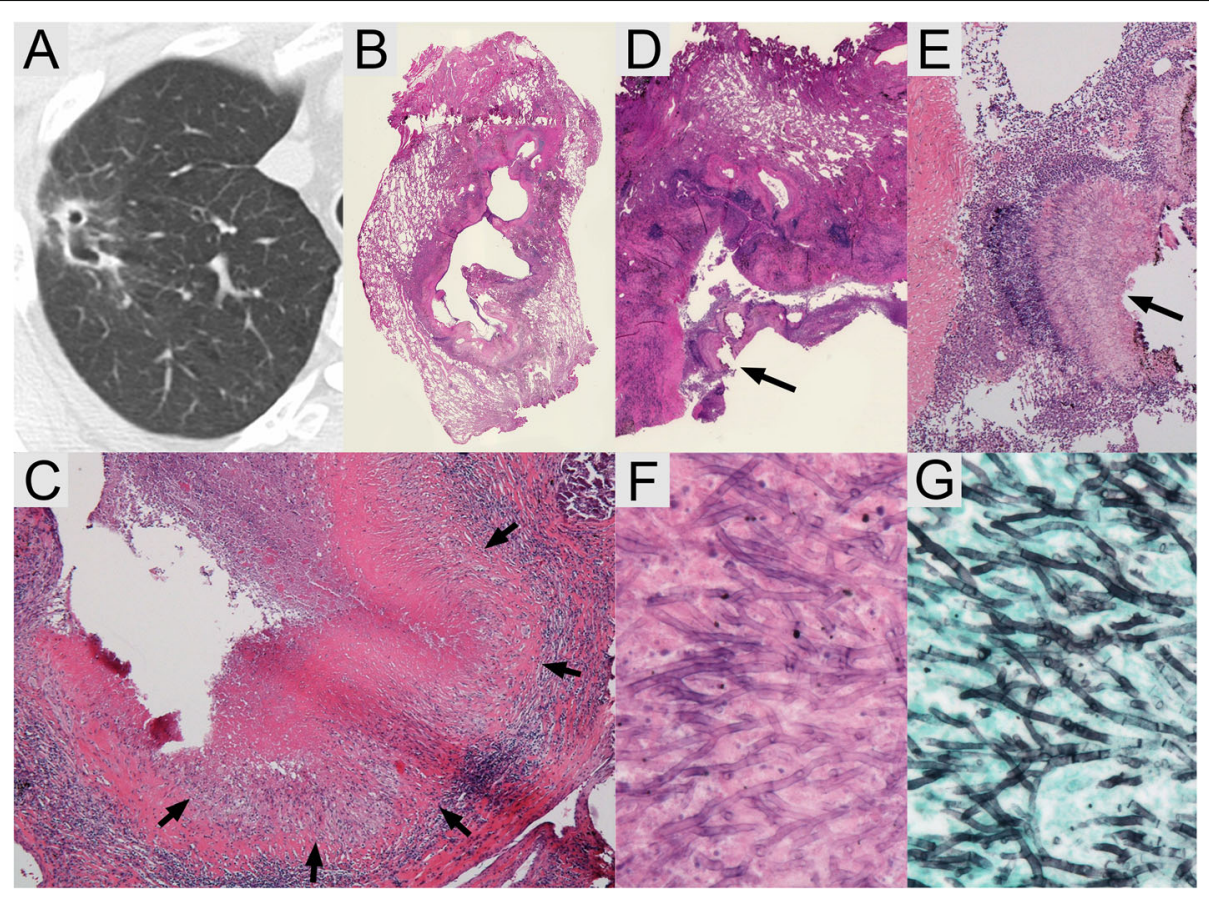

Fig. 2 Imaging study of the chest and histopathological images of resected specimens. a Computed tomography of the chest reveals a cavitary nodule with thin wall and pleural indentations in the right upper lobe. $\mathbf{b}$ The bronchioles surrounding the areas of inflammation and fibrosis are seen in hematoxylin and eosin stained section through a magnifying glass. c The necrotizing granuloma (arrows) destroying and invading the wall of bronchiole is seen in hematoxylin and eosin stained section at low magnification. $\mathbf{d}$ A fungus ball (arrow) is seen in the cavity at the other hematoxylin and eosin stained section through a magnifying glass. e A fungus ball (arrow) is shown at low magnification view in hematoxylin and eosin stained section. $\mathbf{f}$ Y-shaped filamentous fungi in the fungus ball are seen in hematoxylin and eosin stained section at higher magnification. $\mathbf{g}$ The organisms are well outlined with Grocott's methenamine silver stain. The dichotomous branching hyphae and scatter septations can be observed at higher magnification

pulmonary Botrytis sp. infection. As the patient was immunocompetent and the completely resected specimen showed necrotizing granulomas without vascular invasion, he was not offered antifungal agents. The pulmonary Botrytis sp. infection has not recurred 3 years after resectional surgery (Fig. 4).

\section{Mycological features of isolated Botrytis species}

The light microscopy findings stained with lactophenol cotton-blue showed that the mycelium was branched with septa and the conidiophores were also septated. The conidia were single-celled with egg-shaped hyaline and the diameter ranged from approximately $2-3 \times 5-$ $8 \mu \mathrm{m}$ (Fig. 3b). A growth temperature test was performed with incubation on PDA for 7 days at $25^{\circ} \mathrm{C}$ and $35^{\circ} \mathrm{C}$. The growth of the colonies was observed at $25^{\circ} \mathrm{C}$ but not at $35^{\circ} \mathrm{C}$.

Multilocus gene sequence analyses targeting the internal transcribed spacer (ITS) 1 and 2 region and domain 1 and 2 (D1/D2) region of $28 \mathrm{~S}$ rRNA were performed for species identification. The genomic DNA of this isolate was prepared using Go Taq ${ }^{\circ}$ Green Master Mix (Promega Corporation, WI, USA), and PCR was carried out in a Veriti 96 Well Thermal Cycler (Thermo Fisher Scientific K.K.,
Yokohama, Japan). The PCR was performed using the primer pair ITS1 and ITS4 for the ITS region, and the primer pair NL-1 and NL-4 for the D1/D2 region (Table 2) $[5,6]$. Sanger sequencing data of the PCR products were compared with those of the GenBank database search using BLAST. The isolate had $99 \%$ similarity to sequences from B. cinerea, its teleomorph (Botryotinia fuckeliana), $B$. fabiopsis and B. elliptica at the ITS region, and B. cinerea at the D1/D2 region (see Additional file 1: Figures S1 and S2, and Table 3).

As the sequences of ITS and D1/D2 regions do not permit sufficient resolution to the species level in the genus Botrytis [7], we further analyzed three single-copy nuclear DNA genes encoding glyceraldehyde-3-phosphate dehydrogenase (G3PDH), heatshock protein 60 (HSP6O), and DNA-dependent RNA polymerase subunit II (RPB2), which are known to be more discriminatory in attaining the Botrytis species level. The PCR was performed using the primer pairs G3PDHfor/G3PDHrev, HSP60for/HSP60rev and RPB2for/RPB2rev for G3PDH, HSP6O and RPB2, respectively (Table 2) [7]. The PCR products were sequenced and the result of the GenBank database search using BLAST showed that the isolate was 
Table 1 Laboratory data

\begin{tabular}{|c|c|c|}
\hline Variable & On Admission & Reference range, Adults \\
\hline Hemoglobin (g/dl) & 14.1 & $13.1-17.0$ \\
\hline Hematocrit (\%) & 39.3 & $38.0-50.0$ \\
\hline White cell count (per $\mathrm{mm}^{3}$ ) & 6820 & $3500-8500$ \\
\hline \multicolumn{3}{|l|}{ Differential count (\%) } \\
\hline Neutrophils & 72 & $46-73$ \\
\hline Lymphocytes & 23 & $20-45$ \\
\hline Monocytes & 4 & $1-7$ \\
\hline Eosinophils & 1 & $1-3$ \\
\hline Platelet count (per $\mathrm{mm}^{3}$ ) & 188,000 & $150,000-350,000$ \\
\hline Erythrocyte sedimentation rate (mm/hour) & 12 & $1-10$ \\
\hline Blood urea nitrogen (mg/dl) & 16 & $7-19$ \\
\hline Creatinine (mg/dl) & 1.2 & $0.6-1.2$ \\
\hline Total protein (g/dl) & 7.3 & $6.7-8.1$ \\
\hline Albumin $(\mathrm{g} / \mathrm{dl})$ & 4.4 & $4.0-5.0$ \\
\hline Lactate dehydrogenase (U/liter) & 213 & $100-225$ \\
\hline Asparate aminotransferase (U/liter) & 20 & $11-32$ \\
\hline Alanine aminotransferase (U/liter) & 18 & $3-30$ \\
\hline Total bilirubin (mg/dl) & 0.8 & $0.2-1.0$ \\
\hline Y-Glutamyltransferase (U/liter) & 28 & $10-60$ \\
\hline Alkaline phosphatase (U/liter) & 241 & $100-335$ \\
\hline C-reactive protein (mg/dl) & $<0.2$ & $<0.2$ \\
\hline Sodium (mmol/liter) & 142 & 139-147 \\
\hline Potassium (mmol/liter) & 4.1 & $3.5-4.8$ \\
\hline Chloride (mmol/liter) & 107 & $101-111$ \\
\hline Blood sugar (mg/dl) & 123 & $65-110$ \\
\hline Prothrombin time (International normalized ratio) & 1.00 & $0.86-1.12$ \\
\hline Activated partial thromboplastin time (second) & 27.3 & $23.0-35.0$ \\
\hline Hemoglobin A1c (\%) & 5.8 & $4.3-6.1$ \\
\hline Carcinoembryonic antigen (ng/ml) & 2.8 & $<5.0$ \\
\hline Cytokeratin 19 fragment $(\mathrm{ng} / \mathrm{ml})$ & 2.7 & $<3.5$ \\
\hline Progastrin-releasing peptide (pg/ml) & 84.9 & $<81$ \\
\hline Soluble interleukin-2 receptor (U/ml) & 434 & $145-519$ \\
\hline 1, 3- $\beta$-D-glucan (pg/dl) & $<5.5$ & $<11$ \\
\hline Aspergillus antigen (cut off index) & $<0.1$ & $<0.5$ \\
\hline Anti-Aspergillus antibody & Negative & Negative \\
\hline Cryptococcus antigen & Negative & Negative \\
\hline Anti-human immunodeficiency virus antibody (cut off index) & 0.16 & $<1.0$ \\
\hline Anti-human T-cell leukemia virus type 1 antibody (cut off index) & 0.09 & $<1.0$ \\
\hline
\end{tabular}

most similar to B. elliptica (see Additional file 1: Figures S3-S5 and Table 4).

The antifungal susceptibility test of the isolated $\mathrm{Bo}$ trytis species was performed using the broth microdilution assay according to the Clinical and Laboratory Standards Institute approved standard M38-A2 guideline for molds. We tried to evaluate the minimal inhibitory concentration (MIC) of antifungal agents including amphotericin $\mathrm{B}$, micafungin, voriconazole, fluconazole, itraconazole, miconazole, and flucytosine. No growth was observed at any MIC for any antifungal agents including the control media. 


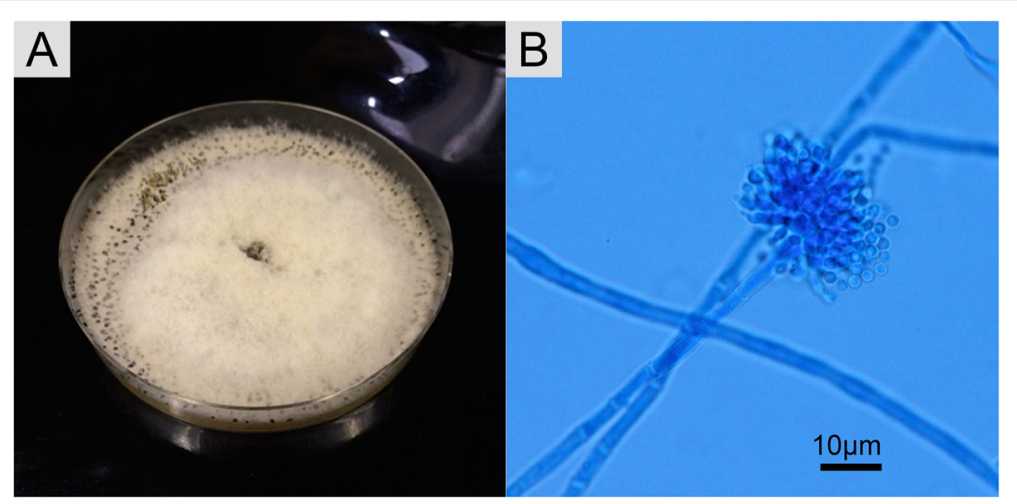

Fig. 3 Morphological characters of the colony. a The white to grayish cotton-like colonies with black sclerotia were cultivated from lung biopsy material on potato dextrose agar for 7 days at $25^{\circ} \mathrm{C}$. $\mathbf{b}$ The mycelium and conidiophores were septated, and the conidia were egg-shaped hyaline

\section{Discussion and conclusions}

This case is the first report of an apparently immunocompetent patient with pulmonary Botrytis sp. infection, which has not recurred after lung resection. Furthermore, the patient did not require any additional medication.

Botrytis species are well known fungal pathogens of various plants and agricultural products but little is known about their pathogenicity in humans. Two clinical studies reported an association between asthma and positive skin prick test reaction to molds including $B$. cinerea $[8,9]$. Korhonen $[8]$ reported that the most common responsive molds were $B$. cinerea, Aspergillus fumigatus and Cladosporium herbarum in young Finnish children newly diagnosed with asthma. Immonen [9] found that allergy toward $B$. cinerea is just as prevalent as allergy toward A. fumigatus, Alternaria alternata, and C. herbarum in Finnish school children having asthma or in those suspected of asthma. Specific IgE antibodies to molds were investigated using a standard mold test panel (Phadebas $\mathrm{RAST}^{\circ}$ ) and an extended mold panel, in which $B$. cinerea was included, in two studies $[10,11]$.
Karlsson-Borga [10] reported that B. cinerea was the second most prevalent mold allergen in Sweden and Denmark, and the most prevalent in the USA in patients with suspected mold allergy. Koivikko [11] found that $B$. cinerea was the fourth most prevalent fungal allergy in 121 asthmatic children. Similar to other fungi, $B$. cinerea contains $1,3-\beta-D$-glucan and chitin in its cell wall. Studies have shown that inhalation of this particular $1,3-\beta$ D-glucan can elicit respiratory inflammation and chitin might also be involved in allergic reactions upon frequent exposure to this polysaccharide [3].

Cases of hypersensitivity pneumonitis/allergic alveolitis caused by $B$. cinerea have been reported in two farm workers working with noble rot grapes (wine grower's lung) [12]. They inhaled spores of $B$. cinerea during grape gathering. Their chest radiograph showed a reticular shadow indicative of pulmonary fibrosis. $B$. cinerea specific IgG antibody was identified using the Ouchterlony immunodiffusion test and the immunofluorescence test in both patients.

There have been no reports of Botrytis infection in humans even though many people likely inhale spores of

Table 2 List of primers employed in polymerase chain reaction in this study

\begin{tabular}{|c|c|c|c|}
\hline Target Region & Primer Name & Primer Sequence (5' to $\left.3^{\prime}\right)$ & Reference \\
\hline \multirow[t]{2}{*}{ ITS } & ITS1 & TCCGTAGGTGAACCTGCGG & \multirow[t]{2}{*}{ [4] } \\
\hline & ITS4 & TCCTCCGCTTATTGATATGC & \\
\hline \multirow[t]{2}{*}{ Domain 1 and 2} & $N L-1$ & GCATATCAATAAGCGGAGGAAAAG & \multirow[t]{2}{*}[5]{} \\
\hline & $\mathrm{NL}-4$ & GGTCCGTGTTTCAAGACGG & \\
\hline \multirow[t]{2}{*}{ G3PDH } & G3PDHfor & ATTGACATCGTCGCTGTCAACGA & \multirow[t]{2}{*}[6]{} \\
\hline & G3PDHrev & ACCCCACTCGTTGTCGTACCA & \\
\hline \multirow[t]{2}{*}{ HSP60 } & HSP60for & CAACAATTGAGATTTGCCCACAAG & \multirow[t]{2}{*}[6]{} \\
\hline & HSP60rev & GATGGATCCAGTGGTACCGAGCAT & \\
\hline \multirow[t]{2}{*}{ RPB2 } & RPB2for & GATGATCGTGATCATTTCGG & \multirow[t]{2}{*}{ [6] } \\
\hline & RPB2rev & CCCATAGCTTGCTTACCCAT & \\
\hline
\end{tabular}


Table 3 BLAST results of sequences at internal transcribed spacer (ITS) region and domain 1 and 2 region

\begin{tabular}{|c|c|c|c|c|}
\hline & ITSfor & ITSrev & Domain 1 and 2for & Domain 1 and 2rev \\
\hline 1 & Botryotinia fuckeliana & Botrytis cinerea & Botrytis cinerea & Botrytis cinerea \\
\hline Identities & 489/491 (99\%) & 482/483 (99\%) & $559 / 560$ (99\%) & 558/559 (99\%) \\
\hline Accession no. & KF533033.1 & MF521935.1 & KU140653.1 & KU729179.1 \\
\hline 2 & Botrytis fabiopsis & Botrytis cinerea & Botrytis cinerea & Botrytis cinerea \\
\hline Identities & 489/491 (99\%) & 482/483 (99\%) & $559 / 560(99 \%)$ & $558 / 559$ (99\%) \\
\hline Accession no. & KR135152.1 & KU291996.1 & KR094468.1 & KT323330.1 \\
\hline 3 & Botrytis elliptica & Botrytis cinerea & Botrytis cinerea & Botrytis cinerea \\
\hline Identities & 489/491 (99\%) & 482/483 (99\%) & $559 / 560$ (99\%) & 558/559 (99\%) \\
\hline Accession no. & KR055047.1 & KT271762.1 & KP671724.1 & KR094468.1 \\
\hline 4 & Botrytis cinerea & Botrytis elliptica & Botrytis cinerea & Botrytis cinerea \\
\hline Identities & 489/491 (99\%) & 483/484 (99\%) & $559 / 560(99 \%)$ & $558 / 559$ (99\%) \\
\hline Accession no. & KR002909.1 & KR055047.1 & СР009808.1 & KP780471.1 \\
\hline 5 & Botrytis cinerea & Botrytis elliptica & Botrytis cinerea & Botrytis cinerea \\
\hline Identities & 489/491 (99\%) & 483/484 (99\%) & $559 / 560(99 \%)$ & $558 / 559$ (99\%) \\
\hline Accession no. & KF859919.1 & KR076789.1 & KM249092.1 & KP671724.1 \\
\hline
\end{tabular}

Botrytis species. Detection of saprophytic molds from sputum or bronchoalveolar lavage samples has generally been considered as contamination or colonization [13]. In our case Botrytis was detected in pure culture from a resected lung nodule. Fungal infections occur in patients with risk factors such as environmental factors, primary or acquired immunodeficiency, and structural lung diseases. Our patient had not stayed or worked in an environment where significant exposure to spores of Botrytis species was likely. He had diabetes mellitus, which is a known risk factor for fungal infections [14], but the patient's diabetes was strictly controlled and hemoglobin A1c was normal. He did not have diseases causing immunosuppression such as acquired immunodeficiency

Table 4 BLAST results of sequences at glyceraldehyde-3-phosphate dehydrogenase (G3PDH), heat-shock protein 60 (HSP60) and DNA-dependent RNA polymerase subunit II (RPB2) genes

\begin{tabular}{|c|c|c|c|c|c|c|}
\hline & G3PDHfor & G3PDHrev & HSP60for & HSP60rev & RPB2for & RPB2rev \\
\hline 1 & B. elliptica & B. elliptica & B. elliptica & B. elliptica & B. elliptica & B. elliptica \\
\hline Identities & $\begin{array}{l}924 / 928 \\
(99 \%)\end{array}$ & $\begin{array}{l}924 / 929 \\
(99 \%)\end{array}$ & $\begin{array}{l}\text { 988/988 } \\
(100 \%)\end{array}$ & $\begin{array}{l}981 / 983 \\
(99 \%)\end{array}$ & $\begin{array}{l}961 / 963 \\
(99 \%)\end{array}$ & $\begin{array}{l}\text { 992/993 } \\
(99 \%)\end{array}$ \\
\hline Accession no. & KP896523.1 & KP896523.1 & KR076786.1 & KR076786.1 & KR076787.1 & KR076787.1 \\
\hline 2 & B. squamosa & B. squamosa & B. squamosa & B. squamosa & B. elliptica & B. elliptica \\
\hline Identities & $\begin{array}{l}\text { 880/884 } \\
\text { (99\%) }\end{array}$ & $\begin{array}{l}882 / 886 \\
(99 \%)\end{array}$ & $\begin{array}{l}975 / 976 \\
(99 \%)\end{array}$ & $\begin{array}{l}974 / 977 \\
(99 \%)\end{array}$ & $\begin{array}{l}961 / 963 \\
(99 \%)\end{array}$ & $\begin{array}{l}965 / 966 \\
(99 \%)\end{array}$ \\
\hline Accession no. & AJ705037.1 & AJ705037.1 & FJ169659.1 & FJ169659.1 & AJ745682.1 & AJ745682.1 \\
\hline 3 & B. ficariarum & B. ficariarum & B. squamosa & B. squamosa & B. squamosa & B. squamoso \\
\hline Identities & $\begin{array}{l}880 / 884 \\
(99 \%)\end{array}$ & $\begin{array}{l}882 / 886 \\
(99 \%)\end{array}$ & $\begin{array}{l}975 / 976 \\
(99 \%)\end{array}$ & $\begin{array}{l}974 / 977 \\
(99 \%)\end{array}$ & $\begin{array}{l}960 / 963 \\
(99 \%)\end{array}$ & $\begin{array}{l}964 / 966 \\
(99 \%)\end{array}$ \\
\hline Accession no. & AJ705016.1 & AJ705016.1 & AJ716098.1 & AJ716098.1 & FJ169682.1 & FJ169682.1 \\
\hline 4 & B. elliptica & B. elliptica & B. elliptica & B. elliptica & B. squamosa & B. squamoso \\
\hline Identities & $\begin{array}{l}880 / 884 \\
(99 \%)\end{array}$ & $\begin{array}{l}882 / 886 \\
(99 \%)\end{array}$ & $\begin{array}{l}975 / 976 \\
(99 \%)\end{array}$ & $\begin{array}{l}\text { 974/977 } \\
(99 \%)\end{array}$ & $\begin{array}{l}960 / 963 \\
(99 \%)\end{array}$ & $\begin{array}{l}964 / 966 \\
(99 \%)\end{array}$ \\
\hline Accession no. & AJ705010.1 & AJ705010.1 & AJ716071.1 & AJ716071.1 & AJ745707.1 & AJ745707.1 \\
\hline 5 & B. squamosa & B. squamosa & B. elliptica & B. elliptica & B. elliptica & B. elliptica \\
\hline Identities & $\begin{array}{l}879 / 884 \\
(99 \%)\end{array}$ & $\begin{array}{l}881 / 886 \\
(99 \%)\end{array}$ & $\begin{array}{l}974 / 976 \\
(99 \%)\end{array}$ & $\begin{array}{l}973 / 977 \\
(99 \%)\end{array}$ & $\begin{array}{l}958 / 963 \\
(99 \%)\end{array}$ & $\begin{array}{l}962 / 966 \\
(99 \%)\end{array}$ \\
\hline Accession no. & EU519214.1 & EU519214.1 & AM232669.1 & AM232669.1 & EU514477.1 & EU514477.1 \\
\hline
\end{tabular}




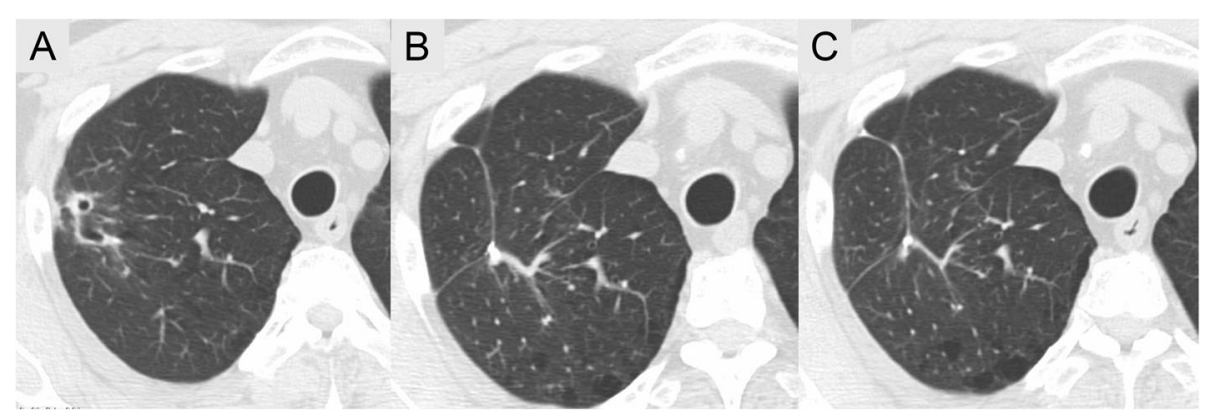

Fig. 4 Subsequent $C T$ scans of the chest. a Computed tomography (CT) of the chest on admission reveals a cavitary nodule with thin wall and pleural indentations in the right upper lobe. $\mathbf{b}$ CT of the chest obtained 1 year after surgery shows an operation scar without any nodules or cavities. c CT of the chest obtained 3 years after surgery shows the same findings as CT 1 year after surgery (b)

syndrome or hematological malignancy, and took neither corticosteroids, nor cytotoxic agents. Recently, biological defense mechanisms against fungal infections have been elucidated [15] and primary immunodeficiencies including chronic granulomatous disease (CGD) or caspase recruitment domain family member 9 deficiency can also predispose to invasive fungal diseases [16]. Although we did not test for CGD or other genetic markers that may confer susceptibility, he had never experienced any fungal infections until this presentation and his family also had no fungal infections. Pulmonary aspergillosis that is unrelated to immunosuppression requires previous airway damage, such as bronchiectasis or bullous disease. This patient had a history of 60 pack-years of smoking cigarettes. The fungus ball can be formed by proliferation of fungi saprophytically in emphysematous bulla. This could not be demonstrated because he had not received a CT scan prior to his clinical presentation within our hospital.

Alternatively, Botrytis lung infection may have been misdiagnosed as Aspergillus infection, when we found Y-shaped filamentous fungi with septa in the resected lung tissue histopathologically without microbiological examination.

The antifungal susceptibility test of the isolated Botrytis species was performed using the Clinical and Laboratory Standards Institute M38-A2 broth microdilution method. No growth was observed at any MIC for any of the antifungal agents including the control media. We tried to incubate the isolate in liquid media including Roswell Park Memorial Institute media 1640 and Sabouraud liquid broth media, but no growth was observed (data not shown). This suggests that the isolated Botrytis species may be difficult to incubate in liquid media.

In conclusion, we report the first case of an apparently immunocompetent patient with pulmonary Botrytis sp. infection, which has not recurred after lung resection without any additional medication. Precise evaluation is necessary for the diagnosis of pulmonary
Botrytis infection, because it is indistinguishable from other filamentous fungi both radiologically and by histopathology. Furthermore, the etiology and pathophysiology of pulmonary Botrytis infection remains unclear. Further accumulation and analysis of Botrytis cases is warranted.

\section{Additional file}

Additional file 1: Figure S1. Sequence data of internal transcribed spacer (ITS) region. Figure S2. Sequence data of domain 1 and 2 region. Figure S3. Sequence data of glyceraldehyde-3-phosphate dehydrogenase (G3PDH) gene. Figure S4. Sequence data of heat-shock protein 60 (HSP60) gene. Figure S5. Sequence data of DNA-dependent RNA polymerase subunit II (RPB2) gene. (PDF $383 \mathrm{~kb}$ )

\section{Abbreviations}

BLAST: Basic Local Alignment Search Tool; CGD: Chronic granulomatous disease; CT: Computed tomography; D1/D2: Domain 1 and 2;

G3PDH: Glyceraldehyde-3-phosphate dehydrogenase; HSP60: Heat-shock protein 60; ITS: Internal transcribed spacer; MIC: Minimal inhibitory concentration; PCR: Polymerase Chain Reaction; PDA: Potato dextrose agar RPB2: DNA-dependent RNA polymerase subunit II; rRNA: ribosomal ribonucleic acid

\section{Acknowledgements}

Not applicable.

Authors' contributions

$\mathrm{SH}, \mathrm{ET}, \mathrm{TH}$ and $\mathrm{YT}$ analyzed and interpreted the patient data comprehensively. SH, MU, ST, TI, YK, TY and TN managed the patient. SN interpreted the radiological examination. GH and YK performed and interpreted the histological examination of the lung. NA and KK performed multi-locus sequence analyses and interpreted the data. SH and ET drafted the manuscript. All authors were involved in the revision of the manuscript. All authors have read and approved the final manuscript.

\section{Funding}

There is no financial support for the study to declare.

Availability of data and materials

All data generated or analyzed during this study are included in this published article and its supplementary information files.

Ethics approval and consent to participate Not applicable. 


\section{Consent for publication}

Written consent from the patient was obtained for publication of this case report.

\section{Competing interests}

The authors declare that they have no competing interests.

\section{Author details}

'Department of Respiratory Medicine, Tenri Hospital, 200 Mishima-cho, Tenri, Nara 632-8552, Japan. ${ }^{2}$ Department of Thoracic Surgery, Tenri Hospital, 200 Mishima-cho, Tenri, Nara 632-8552, Japan. ${ }^{3}$ Department of Radiology, Tenri Hospital, 200 Mishima-cho, Tenri, Nara 632-8552, Japan. ${ }^{4}$ Department of Pathology, Tenri Hospital, 200 Mishima-cho, Tenri, Nara 632-8552, Japan. ${ }^{5}$ Department of Clinical Laboratory, Tenri Hospital, 200 Mishima-cho, Tenri, Nara 632-8552, Japan. ${ }^{6}$ Division of Clinical Research, Medical Mycology Research Center, Chiba University, 1-8-1 Inohana, Chuo-ku, Chiba 260-8673, Japan.

Received: 24 April 2019 Accepted: 25 July 2019

Published online: 02 August 2019

\section{References}

1. Elad Y, Williamson B, Tudzynski P, Delen N. Botrytis: Biology, pathology and control. Netherland: Springer; 2007.

2. Williamson B, Tudzynski B, Tudzynski P, van Kan JA. Botrytis cinerea: the cause of grey mould disease. Mol Plant Pathol. 2007;8(5):561-80.

3. Jurgensen CW, Madsen A. Exposure to the airborne mould Botrytis and its health effects. Ann Agric Environ Med. 2009;16(2):183-96.

4. Hashimoto S, Tanaka E, Ueyama M, Terada S, Nakanishi T, Hamao H, et al. A case of pulmonary Botrytis species infection in an apparently healthy individual [abstract]. Am J Respir Crit Care Med. 2017;195:A7155.

5. White TJ, Bruns T, Lee S, Taylor J. Amplification and direct sequencing of fungal ribosomal RNA genes for phylogenetics. In: Innis MA, Gelfand DH, Sninsky JJ, White TJ, editors. PCR protocols: a guide to methods and applications. London: Academic; 1990. p. 315-22.

6. Kurtzman $\mathrm{CP}$, Robnett $\mathrm{CJ}$. Identification of clinically important ascomycetous yeasts based on nucleotide divergence in the $5^{\prime}$ end of the large-subunit (265) ribosomal DNA gene. J Clin Microbiol. 1997;35(5):1216-23.

7. Staats M, van Baarlen P, van Kan JA. Molecular phylogeny of the plant pathogenic genus Botrytis and the evolution of host specificity. Mol Biol Evol. 2005;22(2):333-46.

8. Korhnen K, Mähönen S, Hyvärinen A, Nevalainen A, Husman T, Pekkanen J, et al. Skin test reactivity to molds in pre-school children with newly diagnosed asthma. Pediatr Int. 2006;48(6):577-81.

9. Immonen J, Meklin T, Taskinen T, Nevalainen A, Korppi M. Skin-prick test findings in students from moisture- and mould-damaged schools: a 3-year follow-up study. Pediatr Allergy Immunol. 2001;12(2):87-94.

10. Karlsson-Borgå A, Jonsson P, Rolfsen W. Specific lgE antibodies to 16 widespread mold genera in patients with suspected mold allergy. Ann Allergy. 1989;63(6):521-6.

11. Koivikko A, Viander M, Lanner A. Use of the extended Phadebas RAST panel in the diagnosis of mould allergy in asthmatic children. Allergy. 1991;46(2): 85-91.

12. Popp W, Ritschka L, Zwick H, Rauscher H. "Berry sorter's lung" or wine grower's lung - an exogenous allergic alveolitis caused by Botrytis cinerea spores. Prax Klin Pneumol. 1987;41(5):165-9.

13. Ullmann AJ, Aguado JM, Arikan-Akdagli S, Denning DW, Groll AH, Lagrou K, et al. Diagnosis and management of Aspergillus diseases: executive summary of the 2017 ESCMID-ECMM-ERS guideline. Clin Microbiol Infect. 2018;24(Suppl 1):e1-e38.

14. Joshi N, Caputo GM, Weitekamp MR, Karchmer AW. Infections in patients with diabetes mellitus. N Engl J Med. 1999;341(25):1906-12.

15. Holland SM, Vinh DC. Yeast infections--human genetics on the rise. N Engl J Med. 2009;361(18):1798-801.

16. Pilmis B, Puel A, Lortholary O, Lanternier F. New clinical phenotypes of fungal infections in special hosts. Clin Microbiol Infect. 2016;22(8):681-7.

\section{Publisher's Note}

Springer Nature remains neutral with regard to jurisdictional claims in published maps and institutional affiliations.

Ready to submit your research? Choose BMC and benefit from:

- fast, convenient online submission

- thorough peer review by experienced researchers in your field

- rapid publication on acceptance

- support for research data, including large and complex data types

- gold Open Access which fosters wider collaboration and increased citations

- maximum visibility for your research: over $100 \mathrm{M}$ website views per year

At BMC, research is always in progress.

Learn more biomedcentral.com/submissions 